ANNA GAJDZICA, EWA OGRODZKA-MAZUR

University of Silesia

in Katowice

MiLAN CHMURA, JOSEF MALACH

University of Ostrava

Czech Republic

\title{
RESEARCH INTO STUDENTS' ICT COMPETENCIES AND THEIR USE IN ICT AT SELECTED UNIVERSITIES. A POLISH - CZECH COMPARATIVE STUDY
}

\begin{abstract}
Gajdzica Anna, Ogrodzka-Mazur Ewa, Chmura Milan, Malach Josef, Research Into Students' ICT Competencies and Their Use in ICT at Selected Universities. A Polish - Czech Comparative Study [Badania nad kompetencjami informatycznymi uczniów i ich wykorzystanie $\mathrm{w}$ nauczaniu tych przedmiotów na wybranych uniwersytetach. Polsko-czeskie stadium porównawcze]. Studia Edukacyjne nr 36, 2015, Poznań 2015, pp. 365-379. Adam Mickiewicz University Press. ISBN 978-83232-2958-2. ISSN 1233-6688. DOI: 10.14746/se.2015.36.21
\end{abstract}

Due to the occurring changes, teaching qualifications cannot be assumed as unchangeable, nor can a permanent list of required pedagogical competences be established. Therefore, what is necessary is appropriate preparation of students - future teachers. This is associated with increasing the effectiveness of teacher training and with the need of lifelong education, which is a requirement of modern times. In this situation, the studies aimed at diagnosing students' competences gain particular significance. They can enable verification and implementation (still at the stage of university studies) of some classes which will ensure optimal professional and social functioning of future teachers.

The studies discussed in the article were conducted in 2014-2015 within the IRNet project: International research network for study and development of new tools and methods for advanced pedagogical science in the field of ICT instruments, e-learning and intercultural competences in Poland, University of Silesia, Faculty of Ethnology and Education in Cieszyn, and in the Czech Republic, University of Ostrava, Pedagogical Faculty. The research aimed at specifying the level of information-communication, intercultural and technological (ICT) competences which Polish and Czech students acquire in the course of education.

Key words: competencies, comparative study, ICT 


\section{Introduction}

The article has been elaborated by a team of Polish and Czech scientists exploring the issues of professional preparation of university students educated at pedagogical courses. The team represents two neighbouring countries in Central Europe, in which many multidimensional changes in education are taking place, including changes in viewing the role and function of the contemporary educational system and upper education. This subject matter is reflected in abundant Polish and Czech expert literature ${ }^{1}$.

Following the issuance of the European Union document A Memorandum of Lifelong Learning ${ }^{2}$, both educational systems accepted national strategies of lifelong learning 3 , which react to the global challenges and needs in education, by defining specific priority aims as well as the means by which these aims can be achieved. The Czech version of the document operates with the following interpretation: "Lifelong learning represents an essential conceptual shift in the very concept of education, its organisational principle, where all possibilities of learning - be it in the traditional educational institutions within the educational system or beyond them - are perceived as one integrated whole allowing diverse and frequent transitions between education and careers and enabling to achieve the same level of qualification and competence in many different ways and in any phase of the lifetime" 4 .

In Poland, the application of lifelong education ideas to the domain of further professional education of teachers was successfully acomplished in 2000 by accepting the rules of career system that motivate teachers to acquire new and deepen the existing professional competences ${ }^{5}$, while in the Czech Republic equally defined career degrees have not been established yet. Po-

${ }^{1}$ These phenomena have been broadly discussed in Polish and Czech publications in the field of sociology, psychology and pedagogy. Cf. e.g. works: ed. T. Lewowicki, "Gorace" problemy edukacji w Polsce, Warszawa 2007; M. Czerepaniak-Walczak, Fabryki dyplomów czy universitas? O "nadwiślańskiej" wersji przemian w edukacji akademickiej, Kraków 2013; Strategia rozwoju szkolnictwa wyższego w Polsce - drugi wariant.https:/ / www.nauka.gov.pl/g2/oryginal/ 2013_05/59579f9e6efaec82014d6d5be081ca23.pdf [Access: 03.05.2015]; Národní program rozvoje vzdělávání v České republice. Bílá kniha, Praha 2001; Mc Kinsey a Comp., Klesající výsledky českého základního a středního školství: Fakta a řešení, Praha 2010; Zpráva o vývoji českého školství, Praha 2009; J. Malach, Z. Sikorová, Educational system of the Czech Republic, [in:] European Education and Training Systems, Ed. S. Juszczyk, Toruń 2014, p. 229-266.

2 A Memorandum of lifelong Learning, EK 2010.

${ }^{3}$ Strategia rozwoju kształcenia ustawicznego do roku 2010, Warszawa 2003; Strategie celoživotního učení ČR, Praha 2007.

4 Strategie celoživotního učení ČR, Praha 2007, p. 7.

5 See: Rozporzadzenie Ministra Edukacji Narodowej z 1 marca 2013 r. w sprawie uzyskiwania stopni awansu zawodowego przez nauczycieli, DzU z 2013, poz. 393. 
land's legal standards ${ }^{6}$ have also provided for Standardy ksztatcenia przygotowującego do wykonywania zawodu nauczyciela. The section Szczegótowe efekty ksztatcenia, point 5, says that 'as regards information technology, after finishing education preparing for the teacher's work, a graduate has acquired the following:

- basic knowledge and skills in the field of information technologies, text processing, use of spreadsheets, use of databases, use of presentation graphics, use of information net services, obtaining and processing information;

- the skill of diversified application of information technology in pedagogical work.

In the Czech Republic, a document of the same kind with congruent legal force has not been accepted yet, although a project focused on the creation of qualification frameworks for specific domains of tertiary education (Q-Ram Project), including the domain called "Teaching", has been carried out.

The new situation requires not only the restructuring of the knowledge acquired by students, its modification, but also completing and updating its components. This leads to transformation of the future educationalist's model of acting. What becomes of crucial importance here are questions concerning competences. Over the recent years, growing significance is attributed to the skill of functioning in the multicultural environment. Economic migrations, which change the image of the society, have become a common phenomenon. On one hand, young Poles and Czechs go abroad and have to learn how to function in a culturally different world. On the other hand, however - their countries are the destination of immigrants who also come from some environments of different tradition. In both cases - the expectations from teachers, raised by intercultural pedagogy, are similar. The young generation should be prepared for functioning in the culturally diversified environment with simultaneous respect for what is own and native - what constitutes the essence of identity.

\section{Definitions of key notions}

Providing a definition of the term competence is associated with many difficulties due to its functioning in many scientific disciplines, such as phi-

\footnotetext{
${ }^{6}$ Rozporządzenie Ministra Nauki i Szkolnictwa Wyższego z 17 stycznia 2012 r. w sprawie standardów kształcenia przygotowującego do wykonywania zawodu nauczyciela.
} 
losophy, psychology, linguistics, ethnology, aesthetics, theory of culture or pedagogy and also within popular knowledge. Many theoretical studies indicate that, owing to in depth reflection on the structure of competence and its psychosocial contexts, it acquires the nature of a paradigm which is of empirical, explicatory and predictive significance. This is particularly important in analyzing the individual's subjectivity and his/her functioning in various fields of individual and group life ${ }^{7}$. In the context of the issues discussed in this study, it is essential to make an attempt at theoretical explanation and organization of the ways in which the notion of competence is understood as well as at formulating such a definition which would be useful in pedagogical analyses.

Referring to F. Masterpasqua's standpoint allows for outlining two complementary approaches to competence. Currently - including his concept, three groups of views on this phenomenon can be distinguished 8 .

The first group of solutions assumes that competence means 'personal properties (knowledge, skills, attitudes) which lead to adaptive payouts in significant environments as well as learnt attitudes and natural capabilities manifested as the skill of confronting, active struggle or handling life problems through the use of cognitive and social abilities ${ }^{\prime 9}$.

The second concept of competence emphasizes 'the emotional and motivational significance of human evaluations and expectations concerning human adaptive abilities rather than these abilities themselves' 10 .

The third group of solutions is an attempt to overcome the extremes of two previous suggestions and constitutes their specific synthesis. In this approach, competence can be defined as 'adaptive, cognitive, emotional, behavioural and social attributes completed with more or less visible human beliefs and expectations concerning the man's access to these attributes or the possibility of applying them in life ${ }^{11}$. Thus, this standpoint highlights both the developmental and social nature of competence, associated with the process of a person's collecting individual experiences - the effects of his/her own activity in contacts with the surrounding cultural reality. Generalizing these remarks, it can be stated that competence is:

${ }^{7}$ M. Dudzikowa, Kompetencje autokreacyjne - czy i jak sa możliwe do nabycia w toku studiów pedagogicznych, [in:] Ewolucja tożsamości pedagogiki, Ed. H. Kwiatkowska, Warszawa 1994, p. 204.

8 F. Masterpasqua, Paradygmat kompetencyjny w praktyce psychologicznej, Nowiny Psychologiczne, 1990, 1-2, p. 4.

9 Ibidem.

10 Ibidem.

${ }^{11}$ Ibidem; U. Jakubowska, Wokót pojęcia "kompetencja społeczna” - ujęcie komunikacyjne, Przegląd Psychologiczny, 1996, 3-4, p. 29-39. 
- a subjective category - of a particular person or group,

- a social category - its acquisition is not a process taking place in an abstract community but in a particular system of situations typical of differentiated environments in which the individual's culturation and socialization processes occur,

- a developmental category - its development does not occur only to a particular human age after which this competence functions always on the same level but it consists in active reorganization and integration of its various forms and types acquired in the whole course of life. Thus, development consists in restructurization, not substitution of the old forms by the new. Moreover, raising the level of certain competences influences others in a supportive way, which ensures both more flexibility at lower levels of a particular competence and relative stability at higher levels. This becomes a characteristic feature of the dynamics of its development ${ }^{12}$.

Such understanding of competence along with specifying its categorial indicators enables a certain definitional suggestion. According to this suggestion, competence denotes the capability of such behaviour in the interaction with the environment (the partner) that - depending on the situation individual aims can be fulfilled and the acquired skills can be used for effective managing the surrounding reality ${ }^{13}$. The usefulness of the suggested approach to competence is especially important for pedagogical analyses and can be particularly helpful in specifying the competences of teachers functioning in multicultural environments.

What seems another major problem is an attempt to describe pedagogical competences in this context. The complexity of the teacher's career as well as the multitude of teaching specializations make it impossible to present a comprehensive description of specific competences in this profession. Therefore, such descriptions are usually selective and refer only to some competences ${ }^{14}$. Discussing pedagogical applications of the notion, Astrid Męczkowska ${ }^{15}$ focuses on two approaches to competence. The first means the adaptive potential of the subject, which allows for adjusting the acts to the current environmental conditions. Here, competence is situated in the behaviourist perspective and applies instrumental character. The second approach is a transgressive concept. The types of activities undertaken by

12 M. Dudzikowa, Kompetencje autokreacyjne, p. 205.

${ }^{13}$ H. Sęk (Ed.), Twórczość i kompetencje życiowe a zdrowie psychiczne, Poznań 1991, p. 51-66.

${ }_{14}$ R. Kwaśnica, Dokształcanie nauczycieli w perspektywie wybranych pytan decyzyjnych, [in:] Pytanie o nauczyciela, Ed. R. Kwaśnica, Prace Pedagogiczne XCIX, Wrocław 1993.

${ }^{15}$ A. Męczkowska, Kompetencja, [in:] Encyklopedia pedagogiczna XXI wieku, t. II, Ed. T. Pilch, Warszawa 2003. 
the subject are prone to creative modification and competences counterbalance human relations with the world.

The pedagogical, or more precisely andragogical competences of teachers of adults (lectors) have been analysed by Malach and Chmura ${ }^{16}$ from the University of Ostrava, Czech Republic. Based on a three-phase data collection, their aim was to find out how much importance students of Andragogy attach to the individual competences and personal qualities of a lector in general (i.e. the assumed state), how - from the same point of view - they reflect the current educational practice (i.e. general real state) and how they evaluate themselves (specific state of development). Comparing the results in the domain of generally desired competences of lectors (assumed state) with their real demonstrations in educational practice (general real state and specific states of development) enables to define current educational needs of lectors and teachers. The research shows that within the future teachers/lectors training it is desirable to pay attention to the development of pedagogical/andragogical competences, namely:

- motivational competence, i.e. the art of inducing the interest of learners in self-education and self-development;

- didactic competence, i.e. specifying the content of instruction and optimal methods;

- expressive competence, i.e. presentation of subject matter, including the application of ICT and formulation of requirements on students' independent work.

\section{Intercultural competences}

What becomes an important task in education of pedagogy students - future teachers - is preparing them for life and functioning in contemporary culturally diversified environments. This process is related to acquiring (in the course of education) intercultural competence (treated as a fundamental component of cognitive and cultural competence), which comprises ${ }^{17}$ :

- personal competences (cognitive, emotional, motivational, selfcreative) - manifested in the experience and engagement in one's own professional development;

16 J. Malach, M. Chmura, Kompetence lektora vzdělávání dospělých jako prèemět andragogické diagnostiky, [in:] Diagnostika a evaluace ve vzdělávání a učení dospělých, Eds. J. Malach, M. Chmura, Ostrava 2014, p. 43-63.

${ }^{17}$ E. Ogrodzka-Mazur, Kompetencja aksjologiczna dzieci w młodszym wieku szkolnym. Studium porównawcze środowisk zróżnicowanych kulturowo, Katowice 2007. 
- competences to intercultural communication - manifested in language and non-language skills in social behaviour;

- competences to identity behaviours - comprising the knowledge and capabilities of cognitive-evaluative behaviour in particular fields (elements) of identity;

- competences to tolerant behaviours - manifested in particular abilities to apply tolerant attitudes, in which some permanent components can be distinguished, such as: values, popular knowledge, evaluation and behaviour;

- competences to transgressive and emancipating behaviours - associated with the abilities to respond actively to the environment, also multicultural one, and to free from prejudices and stereotypes by conscious influence on transforming one's own self and the others in the act of mutual cultural learning.

\section{Information-communication competences}

Information-communication competences are an important skill of contemporary humanity. More and more individual experiences are collected through verbal transmission and appropriate functioning in a group results from effective and skilful communication. The level in which the individual has acquired the orientation how to communicate efficiently is an important criterion of his/her evaluation and the basis for assigning social roles and functions to this individual ${ }^{18}$. Communication competence comprises:

- knowledge of language rules and the ability to apply them,

- ability to diversify speech independently from the type of interlocutor and speech act situation,

- cognitive abilities, which determine constructing and discovering meanings of the interlocutor's utterances,

- ability to establish and maintain interaction by language and nonlanguage means,

- ability to use ritual signs while participating in group rites,

- social abilities, manifested in negotiating the relation between the interlocutors ${ }^{19}$.

18 Ibidem.

${ }_{19}$ M. Kielar-Turska, Dziecko i komunikacja. Jak dziecko staje się kompetentne komunikacyjnie? Wychowanie w Przedszkolu, 1992, 6, p. 323. 


\section{Competences in modern technologies (ICT competences)}

A. Springer defines information-communication competences as 'an effect of the acquired knowledge, supported by experience and a positive attitude to information technologies, manifested in the skills of using the computer and the Internet in order to fulfil the company's goals. Therefore, they constitute the worker's potential oriented towards the application of teleinformation techniques and electronic communication services at work ${ }^{\prime 20}$. As regards the education of university students - future educationalists, it can be assumed that these competences denote the knowledge and skills which determine the capability of efficient use of basic functions of informationcommunication technologies and the motivation to apply them ${ }^{21}$.

\section{Methodological assumptions}

The undertaken research aims at specifying the level of informationcommunication, intercultural and technological competences which students achieve in the course of education. At the conceptual stage of the studies, the following research problems were formulated:

1. How to evaluate university students' ICT competence and what is the rate of development of ICT skills in comparison to other competences?

2. Are there any differences in ITC competences between the Polish and Czech students?

Both quantitative and qualitative methods were applied:

- extended questionnaire for examining competences, including the ones acquired in university education: information, communication, intercultural competences as well as competences concerning modern technologies,

- document analysis: the current curricula of the university course of pedagogy both in Poland and the Czech Republic and the European standards of professional education of teachers,

- free and directed interview with academic teachers conducting classes within the course of pedagogy.

The studies were conducted in 2014-2015 within the IRNet project - International research network for study and development of new tools and methods for advanced pedagogical science in the field of ICT instruments, e-learning and

${ }^{20}$ A. Springer, Wtadcy klawiatury? E-kompetencje polskich pracowników - zasoby poszukiwane czy standard na rynku pracy, Personel i Zarządzanie, 2009, 4, p. 66.

${ }^{21}$ I. Sobieraj, Kompetencje informacyjno-komunikacyjne $i$ międzykulturowe w gospodarce. Od adaptacji do innowacji, Warszawa 2012, p. 14. 
intercultural competences in Poland, University of Silesia, Faculty of Ethnology and Education in Cieszyn, and in the Czech Republic, University of Ostrava, Pedagogical Faculty.

The participants were:

- 112 students of pedagogy in Poland,

- 88 students of pedagogy in the Czech Republic.

Altogether, the studies comprised 200 students - future teachers.

The Faculty of Ethnology and Educational Science conducts research tasks in the field of pedagogy and ethnology. The staff conducts projects within both these disciplines. The faculty is situated in a border town and in the heart of multicultural Cieszyn, Silesia region is the main determinant of the research profile. The Faculty educates 3000 students of pedagogy. The process of academic education comprises such courses as e.g. multi- and intercultural education, computer science and information technology. Students make use of the faculty distance learning platform, based on the MOODLE system, which enhances future teachers' preparation for applying e-learning in their work and for undertaking the function of a tutor.

Currently, the Faculty of Education of the University of Ostrava has almost 3300 students, 1900 in the full-time study programme and 1400 in the combined type of study programme. Most of the courses are pedagogyoriented and dominated by disciplines aimed at future teachers training; subjects are taught in bachelor, master and doctoral programmes by 107 academics. Since 2003, the faculty has realized all the three degrees of study that provide training of experts in the field of using informational technologies in education. The research concentrates on the wide spectrum of subjects taught at primary and secondary schools using ICT (informational and communicational technologies) and also on surveying the results achieved. The faculty disposes of the Moodle system, electronic informational databases and modern, well-equipped lecture theatres, including smart boards.

\section{Conclusions}

The analysis and interpretation of the collected empirical material makes it possible to claim that in the assessment of their competences, students from the University of Silesia differ from their peers from the University of Ostrava. This is confirmed by Wilks test statistics: Wilks Lambda $=0.919905$; parametre $\mathrm{F}=5.6305 ; \mathrm{p}=0.001014<0.05$. The differences are statistically significant. 
Students of the University of Silesia assess higher than their peers from the University of Ostrava their intercultural competences (parametre $\mathrm{F}=15.5746 ; \mathrm{p}=0.000110<0,05)$ and technological competences (parametre $\mathrm{F}=4.5419 ; \mathrm{p}=0.034320<0.05)$. The differences are statistically significant (cf. Figure 1).

It can be supposed that the differences indicating a higher level of intercultural competences of students from the University of Silesia may be determined by:

- the implementation of multi- and intercultural education in the course of university training. Since 2002, the following subjects have become incorporated into the curricula of pedagogy: multi- and intercultural education (currently: basics of multi- and intercultural education) at B.A. studies, multi- and intercultural education with methodology at M.A. studies; religious issues in multicultural communities, everyday communication in education, socialization and education in multicultural communities; as well as school education in multicultural communities (B.A. studies); sociocultural contexts of education, designing educational activities creating individuals (M.A. studies);

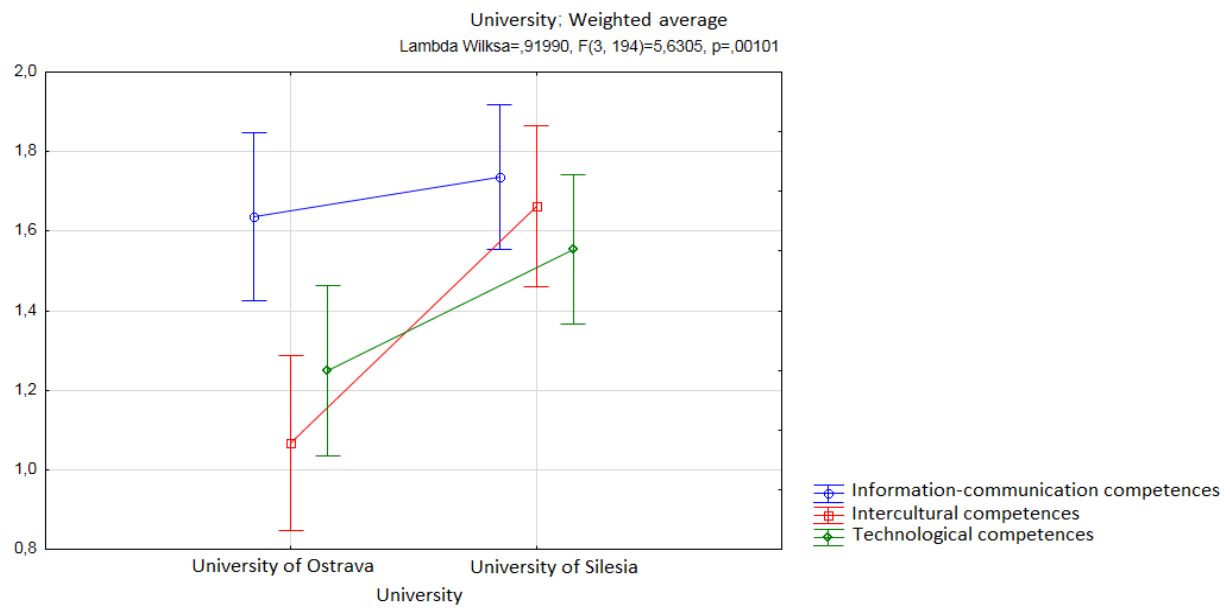

Fig. 1. Level of competences of the examined students from University of Silesia and University of Ostrava

- students' active participation in the Students' Research Team for Intercultural Education, founded in 2004. Its members take part in the studies conducted by the Department of General Pedagogy and Research Methodology and the Department of Social Pedagogy and Intercultural Education, 
they promote the issues of intercultural education among students, youth and children in their local environments and undertake educational (therapeutic and intervention) activities for attributing proper rank to the Other and for supporting the individual in the acquisition of his/her own and social identity. The Team has cooperated with student research teams from other academic centres, with some associations and educational institutions in Poland and worldwide, e.g. with El Camino College in Torrance California USA (since 2005), University of Ostrava (since 2006), Pedagogical Centre for Polish Minority School Education in Czech Republic (since 2006).

- The differences indicating a higher level of information-communication (ICT) competences of students from the University of Silesia might result from introducing into academic curricula some subjects implemented with the use of the Moodle platform. These classes aim at preparing future teachers for the use of distance learning. The Rector's directive (introduced in 2012) allows for fulfilling 50\% of the classes in on-line mode. Moreover, the following subjects have been introduced into obligatory academic education: information technology, information technology in diagnosis and therapy support, information technology in pedagogical therapy. This enhances students' active use of contemporary technologies.

The results of self-evaluation of University of Ostrava students also show greater differences between the individual competences, compared to Polish students who prove to evaluate all observed competences more homogenously. As for Czech students, their evaluation of the domains of informational and communicational technologies is higher than the two remaining competences.

In order to interpret these two crucial empirical findings, it is possible to look for explanation of this phenomenon in the following facts:

- a large proportion of students in the combined form of study programme at the University of Ostrava (44\% of all faculty students). Older students attend a relatively small part of face-to-face education and thus cannot acquire the observed competences to any higher degree. Their formation requires more frequent use of activating and practical, yet timeconsuming, methods - and time might be rather a limited entity for combined programme students, for both space and economic reasons.

- the combined form of study attendants do not take advantage of the possibility to go abroad within the ERASMUS+ programme and thus miss the chance to get into contact with diverse national and ethnic cultures. This might lead to a very low level of intercultural competence acquisition.

- the realisation of the subject Computers in Teaching/Learning Process, which is compulsory for all students of teaching, and also the realisation of 
the above-mentioned ICT in Education course (attended by a small number of students who could, however, participate more willingly in the research of related issues) could contribute to a significantly better self-evaluation of students concerning their informational-communicational competences.

- in the step-by-step process of replacing technological competences by informational-communicational competences in a significant part of population. That could explain the low level of self-evalution in technological competences.

- the implementation of two optional courses Principles of Multicultural Tolerance I and II which might have a positive effect on the intercultural competences of the attendants.

\section{Ending}

From the results of the research of the three selected competences development it is possible to draw several preliminary conclusions, or to use them as a base for formulating drafts of certain curricular modifications inside the future teachers academic training programmes.

The output of the comparison concerning the level of development of the three selected competences of higher education students might indicate a certain educational deficit, signalled by a low level of intercultural and technological competences of the University of Ostrava students.

The relatively close results of self-evaluation of informational-communicational competences in both nationally differentiated groups of respondents suggest the common interests and needs of students as well as the necessity of using the modern digital tools.

The issue of increasing global migration, often caused by local conflicts, should lead to the introduction of the optional subject "Intercultural Competence" that would help future teachers to be better prepared for working with culturally, ethnically, spiritually and ideationally diversified young people, all in the spirit of humanistic traditions of both nations. The accreditation committees of both countries should integrate the process of intercultural competence formation into the basic, recommended core of teacher training.

The respective academics, or academic authorities, should exchange their curriculum documents to draw some inspiration for updates, in harmony with the evolving demands on the content and extent of all the three competences. 
The comparative research has verified the possibilities of applying empirical examinations to larger samples of students, with the use of ICT technologies in all its etapes.

\section{BIBLIOGRAPHY}

A Memorandum of lifelong Learning, EK 2010.

Bolten J., Interkulturowa kompetencja, Wydawnictwo Naukowe UAM, Poznań 2006.

Czerepaniak-Walczak M., Kompetencje nauczyciela w kontekście założeń pedagogiki emancypaсуjnej, [in:] Z pogranicza idei i praktyki edukacji nauczycielskiej, Eds. M. Dudzikowa, A.A. Kotusiewicz, Wydawnictwo UW, Białystok 1994.

Czerepaniak-Walczak M., Fabryki dyplomów czy universitas? O "nadwiślańskiej" wersji przemian w edukacji akademickiej, Oficyna Wydawnicza Impuls, Kraków 2013.

Deardorff D.K., Identification and assessment of intercultural competence as a student outcome of internalization, Journal of Studies in Intercultural Education, 2006, 10.

Dudzikowa M., Kompetencje autokreacyjne - czy i jak sa możliwe do nabycia w toku studiów pedagogicznych, [in:] Ewolucja tożsamości pedagogiki, Ed H. Kwiatkowska, Wydawnictwo PTP, Warszawa 1994.

Gajdzica A., Kompetencje pedagoga wczesnoszkolnego w warunkach środowiska wielokulturowego, [in:] Praca nauczyciela w warunkach wielokulturowości - studia $i$ doświadczenia z pogranicza polsko-czeskiego, Eds. T. Lewowicki, E. Ogrodzka-Mazur, A. Szczurek-Boruta, Wydawnictwo Wydział Etnologii i Nauk o Edukacji UŚ, WSP ZNP w Warszawie, Wydawnictwo Adam Marszałek, Torun 2008.

Hipkins R., Assessing Key Competencies: Why would we? How could we? Ministry of Education, New Zealand, 2007. http:/ / nzcurriculum.tki.org.nz/Archives/Implementationpacks/Assessing-key-competencies-Why-would-we-How-could-we.

Jakubowska U., Wokót pojęcia "kompetencja społeczna” - ujęcie komunikacyjne, Przegląd Psychologiczny, 1996, 3-4.

Kielar-Turska M., Dziecko i komunikacja. Jak dziecko staje się kompetentne komunikacyjnie? Wychowanie w Przedszkolu, 1992, 6.

Kielar-Turska M., Białecka-Pikul M., Dziecko i komunikacja: lingwistyczny, społeczny i poznawczy aspekt badań, Kwartalnik Polskiej Psychologii Rozwojowej, 1993, 1.

Kozielecki J., Transgresja i kultura, Wydawnictwo Akademickie Żak, Warszawa 1997.

Kwaśnica R., Doksztatcanie nauczycieli w perspektywie wybranych pytań decyzyjnych, [in:] Pytanie o nauczyciela, Ed R. Kwaśnica, Prace Pedagogiczne XCIX, Wrocław 1993.

Lewowicki T. (Eds.), "Gorace" problemy edukacji w Polsce, Komitet Nauk Pedagogicznych PAN, WSP ZNP w Warszawie, Warszawa 2007.

Lewowicki T., O badaniach społeczności pogranicza - od parcjalnych opisów ku elementom teorii zachowań tożsamościowych, [in:] Edukacja międzykulturowa - w kręgu potrzeb, oczekiwań i stereotypów, Ed J. Nikitorowicz, Wydawnictwo Uniwersyteckie Trans Humana, Białystok 1995. 
Lewowicki T., Problemy tożsamości narodowej - w poszukiwaniu sposobów uogólnionych ujęć kwestii poczucia tożsamości i zachowań z tym poczuciem zwiazanych, [in:] Edukacja a tożsamość etniczna, Ed M.M. Urlińska, Wydawnictwo UMK, Torun 1995.

Lustig M.W., Koester J., Intercultural Competence. Intercultural Communication Cross Cultures, Allyn and Bacon, Boston 2010.

Magala S., Kompetencje międzykulturowe, Wydawnictwo Wolters Kluwer, Warszawa 2011.

Malach J., Chmura M., Kompetence lektora vzdělávání dospělých jako predmět andragogické diagnostiky, [in:] Diagnostika a evaluace ve vzdělávání a učení dospělých, Eds. J. Malach, M. Chmura, University of Ostrava, Ostrava 2014.

Malach J., Sikorová Z., Educational system of the Czech Republic, [in:] European Education and Training Systems, Ed S. Juszczyk, Wydawnictwo Adam Marszałek, Torun 2014.

Malach J., Klíčové kompetence v kontextu cílu edukace a jejich hodnocení, [in:] Hodnocení klícových kompetencí ve školni edukaci, Eds. J. Malach, I. Červenková, Ostravská univerzita v Ostravě, Ostrava 2014.

Masterpasqua F., Paradygmat kompetencyjny w praktyce psychologicznej, Nowiny Psychologiczne, 1990, 1-2.

Mc Kinsey a Comp., Klesající výsledky českého základního a středního školství: Fakta a řešení, Praha 2010.

Męczkowska A., Kompetencja, [in:] Encyklopedia pedagogiczna XXI wieku, t. II, Ed T. Pilch, Wydawnictwo Akademickie Żak, Warszawa 2003.

Národní program rozvoje vzdělávání v České republice. Bílá kniha, MŠMT, Praha 2001.

Nikitorowicz J., Sobecki M., Danilewicz W., Muszyńska J., Misiejuk D., Bajkowski T., Kompetencje do komunikacji międzykulturowej w aspekcie tradycyjnej wielokulturowości regionu i procesów migracyjnych,. Wydawnictwo Akademickie Żak, Warszawa 2013.

Ogrodzka-Mazur E., Kompetencja aksjologiczna dzieci w młodszym wieku szkolnym. Studium porównawcze środowisk zróżnicowanych kulturowo, UŚ, Katowice 2007.

Rozporządzenie Ministra Edukacji Narodowej z 1 marca 2013 r. w sprawie uzyskiwania stopni awansu zawodowego przez nauczycieli, DzU z 2013, poz. 393.

Rozporządzenie Ministra Nauki i Szkolnictwa Wyższego z 17 stycznia 2012 r. w sprawie standardów kształcenia przygotowującego do wykonywania zawodu nauczyciela /Directive of the Minister of Science and Higher Education of 17th January 2012 on standards in education preparing for the teacher's profession/

Serdyński A., Kompetencje informatyczno-medialne nauczyciela, USz, Szczecin 2007.

Sęk H. (Eds.), Twórczość i kompetencje życiowe a zdrowie psychiczne, Wydawnictwo Naukowe UAM, Poznań 1991.

Skrzypek J., Tak zwane kompetencje kluczowe, ich charakter i potrzeba ksztattowania w toku edukacji ustawicznej, [in:] Pedagogika i edukacja wobec nadziei i zagrożeń wspótczesności, Eds. J. Gnitecki, J. Rutkowiak, Wydawnictwo PTP, Warszawa - Poznań 1999.

Sobieraj I., Kompetencje informacyjno-komunikacyjne $i$ międzykulturowe w gospodarce. Od adaptacji do innowacji, Wydawnictwo Naukowe Scholar, Warszawa 2012.

Sochaczewska P., Kompetencje informatyczne i medialne nauczyciela, [in:] Kompetencje wspótczesnego nauczyciela, Ed K. Żegnałek, WSP TWP, Warszawa 2008.

Spitzbergd B.H., Changnon G., Conceptualizating intercultural competence, [in:] Intercultural Competence, Ed D.K. Deardorff, Sage Publ, Los Angeles-London-New DelhiSingapore-Washington 2009. 
Springer A., Wtadcy klawiatury? E-kompetencje polskich pracowników - zasoby poszukiwane czy standard na rynku pracy, Personel i Zarządzanie, 2009, 4.

Standardy wykształcenia zawodowego nauczycieli. Projekt, MEN, Warszawa 1999.

Strategia rozwoju ksztatcenia ustawicznego do roku 2010, MENiS, Warszawa 2003.

Strategia rozwoju szkolnictwa wyższego w Polsce - drugi wariant. https://www.nauka. gov.pl/g2/oryginal/2013_05/59579f9e6efaec82014d6d5be081ca23.pdf [Access: 03.05. 2015].

Strategie celoživotniho učení ČR, MŠMT, Praha 2007.

Thematic working group "Assessment of key competences", Brussels 2012, European Commission, Dostupné z: http://ec.europa.eu/education/policy/school/doc/keyreview_ en.pdf

Zpráva o vývoji českého školstuí, MŠMT, Praha 2009. 